\title{
Testing for Chlamydia Reinfection Among Adolescent Patients in Different Clinical Settings
}

\section{How Are We Doing?}

\author{
Kate Kollars, BS | Melissa Plegue, MA | Margaret Riley, MD \\ Published: 8/31/2017 | DOI: 10.22454/PRiMER.2017.582445
}

\section{Abstract}

Introduction: Chlamydia trachomatis is the most frequently reported infectious disease in the United States, with high reinfection rates and highest prevalence among adolescents and young adults. National guidelines suggest testing for reinfection 3 months after chlamydia treatment, and 3 to 4 weeks after treatment during pregnancy. Our needs assessment evaluated retesting rates among adolescent and young adult patients across several clinical settings within one community.

Methods: We performed retrospective chart reviews to examine chlamydia retest rates among 14 to 21 -yearold patients treated for chlamydia within three different settings: an academic primary care site with family medicine and pediatrics clinics, an adolescent health center, and a group of school-based health centers (SBHCs). Per CDC guidelines, the goal treatment window was defined as retests conducted between 60 to 183 days after documented treatment for nonpregnant patients, and those conducted within 21 to 42 days posttreatment for pregnant patients.

Results: Overall, $77 / 134$ (57.5\%) of patients were retested, with 59/143 (44\%) retested within the goal time frame. Site rates of retesting within guideline timeframe were as follows: $38.5 \%$ at the academic family medicine site, $46.2 \%$ at the academic pediatrics site, $42.7 \%$ at the adolescent health center, and $55.0 \%$ at SBHCs. The reinfection rate among those appropriately retested was $22.0 \%(13 / 59)$. Of patients not retested appropriately, $25.3 \%$ had return visits at which they were not retested (a missed opportunity).

Conclusions: Our results indicate a need for interventions that encourage patients to return for retesting, and that trigger retesting during unrelated return visits.

\section{Introduction}

Chlamydia trachomatis is the most reported infectious disease in the United States, with its highest prevalence among those under 24 years old. Among 15 to 19 -year-old women, the prevalence is 2,941 per $100,000 .{ }^{1}$ Chlamydia sequelae can include pelvic inflammatory disease, increased ectopic pregnancy risk, and infertility, with repeat infections conferring greater risk. $^{2}$ Although cure rates with antibiotics are high, reinfection rates are high as well, ranging from 7 to $38 \%$ among adolescents in various studies. ${ }^{3-7}$

Current CDC guidelines recommend testing for reinfection 3 months after treatment. Tests of cure 3 to 4 weeks posttreatment to detect antibiotic failure are recommended only for pregnant women. Despite these guidelines, low retest and high reinfection rates indicate many patients do not receive proper follow-up. In one large study, only $22.3 \%$ of men and $38 \%$ of nonpregnant women were retested within 12 months. ${ }^{8}$ School-based health services have 
been found to be effective in chlamydia screening, ${ }^{9}$ but there has been little evaluation to see if they are also effective for retesting.

Our needs assessment sought to examine retesting and reinfection rates among adolescents in one Michigan community, comparing adherence to guidelines between school-based health centers (SBHCs), a private adolescent and young adult clinic, and an academic family medicine and pediatrics primary care site. We also assessed for missed opportunities (ie return clinic appointments without retesting completed), and examined associations between patient demographics and retesting. This study aimed to assess the need for interventions to increase retest rates.

\section{Methods}

We performed retrospective chart reviews on all male and female patients 14 to 21 years old with a positive Chlamydia trachomatis test between September 1, 2014, and August 31, 2015. The demographics of the population studied are shown in Table 1. Based on CDC guidelines, the goal treatment window was defined as tests for reinfection conducted between 60 to 184 days after documented treatment for nonpregnant patients, and tests of cure conducted within 21 to 42 days posttreatment for pregnant patients.

After identifying the initial positive chlamydia test, we reviewed the chart to assess if a subsequent chlamydia test was performed, up to 6 months post-initial treatment. If a patient had a repeat positive chlamydia test that fell within the date range of this study, we noted this and reviewed the chart for an additional 6 months to look for an appropriate test of reinfection after treatment. We also assessed missed opportunities for retesting, defined as a return clinic visit within the goal window during which a retest was not sent. In instances where retests were performed at a different site from the initial treatment location, retests were categorized with the initial site for analysis.

We performed Fisher's exact tests and independent sample t-tests using Stata 13.1 to assess for differences in retest rates, missed opportunities, and reinfection rates between sites and based on patient demographics. The University of Michigan Medical Institutional Review Board reviewed this research and determined it to be "not regulated" as quality improvement.

\section{Results}

Treatment information was available for 134 adolescents with positive chlamydia tests during the study period. Treatment information was not available for nine patients with positive initial tests, for whom the county health department was notified. Overall, $57.5 \%$ (77/134) of patients were retested, with $44.0 \%$ (59/134) retested in the appropriate time frame. Of those tested outside the timeframe $(11.9 \%, 16 / 134), 14$ were tested too soon to be considered a test of reinfection and two were pregnant patients tested after 6 weeks. At the adolescent and young adult clinic, $42.7 \%$ of patients were appropriately retested, vs $46.2 \%$ at the academic pediatrics site, and $38.5 \%$ at the academic family medicine site. SBHCs had the highest retest rates, retesting $55.0 \%$ of patients appropriately (Table 2). These differences between sites were not statistically significant $(P$-value $=0.71)$. No significant differences in likelihood of retesting were found based on race, ethnicity, age, or gender (Table 3).

Of patients not appropriately retested $(n=75), 25.3 \%(19 / 75)$ had at least one missed opportunity. There were no statistically significant differences in missed opportunities between sites (exact $P$-value=0.572).

Of appropriately retested patients, $22.0 \%(13 / 59)$ had a second positive chlamydia test result at their test of reinfection.

\section{Conclusions}

Appropriately testing for and treating chlamydia reinfection can significantly reduce the burden of disease. Although 
rates of retesting within 6 months after treatment in this study were higher than others in the literature, $8,10,11$ these clinical sites were not consistently following CDC guidelines for chlamydia management. Overall, $44.0 \%$ of patients were retested per guidelines, showing significant room for improvement. Proper follow up among adolescents and young-adults is vital to reducing transmission because of their high reinfection rates, supported by the $22 \%$ reinfection rate in this study.

Our ability to compare sites was hindered by small sample size, but more research into the effectiveness of SBHCs for management and retesting of chlamydia is warranted. The SBHCs in this setting retested $55 \%$ of their patients per CDC guidelines, retested $80 \%$ within 6 months, and had few missed opportunities during the study time frame, surpassing other sites. SBHCs' location maximizes patient access, reducing the number of "no-returns," and improving retesting. In certain settings, it may be advantageous for community and private clinics to partner with SBHCs to improve care for adolescent and young adult patients with sexually transmitted infections.

Of the patients not retested in this study, the majority had not returned to clinic. This supports beliefs expressed in the literature by providers that retesting rates are low because patients don't return. ${ }^{12}$ However, other studies note that up to $41.9 \%$ of patients not retested by 6 months had, in fact, returned to clinic during that time. ${ }^{10}$ Our results differ in that only $25.3 \%$ of patients who were not retested per guidelines had missed opportunities. It should also be noted that we were unable to track if patients received retesting at sites outside of this study's health care system.

Interventions such as text message reminders and chart flagging systems may improve chlamydia retesting rates. ${ }^{11-15}$ Moving forward, we plan to institute and evaluate interventions to reduce missed opportunities, increase patient return rates, and improve retesting in this study's population.

\section{Tables and Figures}


Table 1: Study Demographics

\begin{tabular}{|c|c|}
\hline Variable & $\begin{array}{l}\text { Positive Chlamydia Cases } \\
(n=134)\end{array}$ \\
\hline Age, mean (SD) & $18.4(2.1)$ \\
\hline \multicolumn{2}{|l|}{ Gender, n (\%) } \\
\hline Male & $21(15.7)$ \\
\hline Female & $113(84.3)$ \\
\hline \multicolumn{2}{|l|}{ Race, n (\%) } \\
\hline Black & $96(71.6)$ \\
\hline White & $19(14.2)$ \\
\hline Other & $9(6.7)$ \\
\hline Unknown & $10(7.5)$ \\
\hline \multicolumn{2}{|l|}{ Hispanic, $\mathrm{n}(\%)$} \\
\hline Yes & $6(4.5)$ \\
\hline No & $116(86.5)$ \\
\hline Unknown & $12(9.0)$ \\
\hline \multicolumn{2}{|l|}{ Site, $\mathbf{n}(\%)$} \\
\hline Adolescent Health Clinic & $75(56.0)$ \\
\hline SBHCs* & $20(14.9)$ \\
\hline Family Medicine & $26(19.4)$ \\
\hline Pediatrics & $13(9.7)$ \\
\hline \multicolumn{2}{|l|}{ Pregnant, n (\%) } \\
\hline Yes & $15(11.2)$ \\
\hline No & $119(88.8)$ \\
\hline
\end{tabular}

${ }^{*} \mathrm{SBHCs}=$ school-based health centers

Table 2: Differences in Chlamydia Retesting Rates (Per CDC Guidelines) Among 14-21-year-olds Between Clinical Settings

\begin{tabular}{|c|c|c|c|c|c|}
\hline & $\begin{array}{l}\text { Adolescent } \\
\text { and Young } \\
\text { Adult Clinic } \\
\qquad(n=75)\end{array}$ & $\begin{array}{l}\text { School } \\
\text { Based } \\
\text { Health } \\
\text { Centers } \\
(n=20)\end{array}$ & $\begin{array}{c}\text { Academic } \\
\text { Family } \\
\text { Medicine } \\
\text { Site }(n=26)\end{array}$ & $\begin{array}{c}\text { Academic } \\
\text { Pediatrics } \\
\text { Site } \\
(n=13)\end{array}$ & P-value \\
\hline Retested, \% (n) & $50.7 \%(38)$ & $80.0 \%(16)$ & $61.5 \%(16)$ & $53.9 \%(7)$ & 0.121 \\
\hline Not Retested, \% (n) & $49.3 \%(37)$ & $20.0 \%(4)$ & $38.5 \%(10)$ & $46.1 \%(6)$ & \\
\hline $\begin{array}{l}\text { Breakdown of those } \\
\text { retested }\end{array}$ & $n=38$ & $n=16$ & $n=16$ & $n=7$ & \\
\hline Retested per guidelines & $84.2 \%(32)$ & $81.3 \%(13)$ & $62.5 \%(10)$ & $85.7 \%(6)$ & 0.357 \\
\hline $\begin{array}{l}\text { Retested outside of guideline } \\
\text { timeframe }\end{array}$ & $15.8 \%(6)$ & $18.7 \%(3)$ & $37.5 \%(6)$ & $14.3 \%(1)$ & \\
\hline $\begin{array}{l}\text { Breakdown of those not } \\
\text { retested: }\end{array}$ & $n=37$ & $n=4$ & $n=10$ & $n=6$ & \\
\hline Returned but no retest & $16.2 \%(6)$ & $0.0 \%(0)$ & $30.0 \%(3)$ & $33.3 \%(2)$ & 0.433 \\
\hline No return, no retest & $83.8 \%(31)$ & $100.0 \%(4)$ & $70.0 \%(7)$ & $66.7 \%(4)$ & \\
\hline
\end{tabular}

*These patients were retested less than 2 months post-chlamydia treatment for non-pregnant patients or greater than 6 weeks post chlamydia treatment for pregnant patients. 
Table 3: Chlamydia Retesting Rates (Per CDC Guidelines) Among 14-21-Year-Olds Across Demographics

\begin{tabular}{|c|c|c|c|}
\hline Variable & $\begin{array}{c}\text { Not Retested } \\
(\mathbf{n = 7 5 )}\end{array}$ & $\begin{array}{c}\text { Retested } \\
(\mathbf{n}=59)\end{array}$ & P-value \\
\hline Age, mean (SD) & $18.7(2.1)$ & $18.0(2.0)$ & 0.051 \\
\hline Gender, $\mathbf{n}$ (\%) & & & 0.055 \\
\hline Male & $16(21.3)$ & $5(8.5)$ & \\
\hline Female & $78.7(59)$ & $54(91.5)$ & 0.372 \\
\hline Race, $\mathbf{n}$ (\%) & & & \\
\hline Black & $55(77.5)$ & $41(77.4)$ & \\
\hline White & $9(12.7)$ & $10(18.9)$ & \\
\hline Other & $7(9.9)$ & $2(3.8)$ & \\
\hline Hispanic, $\mathbf{n}$ (\%) & $4(5.7)$ & $2(3.9)$ & \\
\hline Yes & $66(94.3)$ & $50(96.2)$ & \\
\hline No & $5(8.5)$ & & \\
\hline Pregnant (among females only), $\mathbf{n}(\%)$ & $54(91.5)$ & $10(18.5)$ & \\
\hline Yes & & $44(81.5)$ & \\
\hline No & & & \\
\hline
\end{tabular}

\section{Corresponding Author}

Kate Kollars, BS

University of Michigan Medical School - Family Medicine, 2025 Traverwood Dr. Suite A6, Ann Arbor, MI 48105

kollarsk@med.umich.edu

\section{Author Affiliations}

Kate Kollars, BS - University of Michigan Medical School, Department of Family Medicine

Melissa Plegue, MA - University of Michigan Medical School, Department of Family Medicine

Margaret Riley, MD - University of Michigan Medical School, Department of Family Medicine

\section{References}

1. CDC. 2014 Sexually Transmitted Diseases Surveillance: Chlamydia. http://www.cdc.gov/std/stats14 /chlamydia.htm. Accessed January 15, 2016.

2. CDC. 2015 Sexually Transmitted Diseases Treatment Guidelines: Chlamydia. http://www.cdc.gov/std/tg2015 /chlamydia.htm. Accessed January 15, 2016.

3. Rietmeijer CA, Van Bemmelen R, Judson FN, Douglas JM Jr. Incidence and repeat infection rates of Chlamydia trachomatis among male and female patients in an STD clinic: implications for screening and rescreening. Sex Transm Dis. 2002;29:65-72. https://doi.org/10.1097/00007435-200202000-00001.

4. Whittington $\mathrm{WL}$, Kent $\mathrm{C}$, Kissinger $\mathrm{P}$, et al. Determinants of persistent and re- current Chlamydia trachomatis infection in young women: results of a multi- center cohort study. Sex Transm Dis. 2001;28:117-123. https://doi.org/10.1097/00007435-200102000-00011.

5. Fortenberry JD, Brizendine EJ, Katz BP, Wools KK, Blythe MJ, Orr DP. Subsequent sexually transmitted infections among adolescent women with genital infection due to Chlamydia trachomatis, Neisseria 
gonorrhoeae, or Trichomonas vaginalis. Sex Transm Dis. 1999;26:26-32.

https://doi.org/10.1097/00007435-199901000-00005.

6. Oh MK, Cloud GA, Fleenor M, Sturdevant MS, Nesmith JD, Feinstein RA. Risk for gonococcal and chlamydial cervicitis in adolescent females: incidence and recurrence in a prospective cohort study. J Adolesc Health. 1996;18:270-275. https://doi.org/10.1016/1054-139X(95)00232-H.

7. Blythe MJ, Katz BP, Batteiger BE, Ganser JA, Jones RB. Recurrent genitourinary chlamydial infections in sexually active female adolescents. J Pediatr. 1992; 121:487-493.

https://doi.org/10.1016/S0022-3476(05)81812-8.

8. Hoover KW, Tao G, Nye MB, Body BA. Suboptimal adherence to repeat testing recommendations for men and women with positive Chlamydia tests in the United States, 2008-2010. Clin Infect Dis. 2013 Jan;56(1):51-57. https://doi.org/10.1093/cid/cis771.

9. Rebecca A. Braun and Jackie M. Provost. Bridging the gap: using school-based health services to improve chlamydia screening among young women. American Journal of Public Health: September 2010, Vol. 100, No. 9, pp. 1624-1629.

https://doi.org/10.2105/AJPH.2009.186825.

10. Teplow-Phipps R, Stockwell MS, Soren K. Adolescent chlamydia infection: treatment, expedited partner therapy, and testing for reinfection. Clin Pediatr (Phila). 2015;54(14):1383 https://doi.org/10.1177/0009922814566934.

11. Kampman C, Koedijk F, Driessen-hulshof H, Hautvast J, Van den broek I. Retesting young STI clinic visitors with urogenital Chlamydia trachomatis infection in the Netherlands; response to a text message reminder and reinfection rates: a prospective study with historical controls. Sex Transm Infect. 2015;0:1-6. https://doi.org/10.1136/sextrans-2015-052115.

12. Park IU, Amey A, Creegan L, Barandas A, Bauer HM. Retesting for repeat chlamydial infection: family planning provider knowledge, attitudes, and practices. J Womens Health (Larchmt). 2010 Jun;19(6):1139-1344. https://doi.org/10.1089/jwh.2009.1648.

13. Guy R, Wand $H$, Knight V, Kenigsberg A, Read P, McNulty AM. SMS reminders improve re-screening in women and heterosexual men with chlamydia infection at Sydney Sexual Health Centre: a before-and-after study. Sex Transm Infect. 2013 Feb;89(1):11-15. https://doi.org/10.1136/sextrans-2011-050370.

14. Nyatsanza F, McSorley J, Murphy S, Brook G. 'It's all in the message': the utility of personalised short message service (SMS) texts to remind patients at higher risk of STIs and HIV to reattend for testing-a repeat before and after study. Sex Transm Infect. 2016 Aug;92(5):393-395.

https://doi.org/10.1136/sextrans-2015-052216.

15. Zou H, Fairley CK, Guy R, Chen MY. The efficacy of clinic-based interventions aimed at increasing screening for bacterial sexually transmitted infections among men who have sex with men: a systematic review. Sex Transm Dis. 2012 May;39(5):382-387. https://doi.org/10.1097/OLQ.0b013e318248e3ff.

Copyright $\odot 2017$ by the Society of Teachers of Family Medicine 